\title{
Enhancement of Postsynaptic Sensitivity to Dopaminergic Agonists Induced by Neonatal Hippocampal Lesions
}

\author{
Rui-Qian Wan, Ph.D., and Roy Corbett, Ph.D.
}

The effects of neonatal hippocampal lesions on behavioral responsiveness to dopaminergic agonists and antagonists were examined. The ventral hippocampus was damaged bilaterally using ibotenic acid on postnatal day 7 , and locomotor responses to dopaminergic agonists and antagonists were evaluated on postnatal day 35 (PD35), 56 (PD56), and 70 (PD70). Quinpirole (0.06, 0.125, 0.25, and $0.5 \mathrm{mg} / \mathrm{kg} \mathrm{SC}$ ), but not SKF38393 (5 and $10 \mathrm{mg} / \mathrm{kg} \mathrm{SC}$ ), increased locomotion in a dose-dependent manner in control and lesioned groups on PD35 and PD56. However, lesioned rats displayed a greater behavioral response to quinpirole than controls at the doses of 0.25 and $0.5 \mathrm{mg} / \mathrm{kg}$ on both
PD35 and PD56. Amphetamine (1.5 $\mathrm{mg} / \mathrm{kg} I P)$ increased locomotor activity in both groups on PD70, but this effect was greater in lesioned rats than in controls. Raclopride $(0.25$ and $0.5 \mathrm{mg} / \mathrm{kg} \mathrm{SC})$ and SCH23390 (0.01 and 0.02 $\mathrm{mg} / \mathrm{kg} \mathrm{SC}$ ) blocked the amphetamine-induced hyperlocomotion in the lesioned and control groups. These results suggest that neonatal hippocampal lesion-induced behavioral hyperresponsiveness to amphetamine is likely related to an increased postsynaptic sensitivity of the $D_{2}$ subtype of receptors. [Neuropsychopharmacology 16:259-268, 1997] (C) 1997 American College of Neuropsychopharmacology
KEY WORDS: Amphetamine; Dopamine $D_{1}$; Dopamine $D_{2}$; Hippocampus; Locomotion; Neonatal lesions; Neurotoxin

Abnormal neurodevelopmental processes may be involved in some aspects of schizophrenia (Weinberger 1987; Mednick et al. 1991; Kerwin and Murray 1992; Bloom 1993). Clinical studies have suggested that regional neuropathology during early development may result in behavioral abnormalities in later life (Weinberger 1987; Bloom 1993; Kotrla and Weinberger 1994). Neuropathological changes in the hippocampus have been described in schizophrenic brains (Brown et al. 1986; Falkai and Bogerts 1986; Beckmann et al. 1987; Bo-

From Neuroscience PGU, Hoechst Marion Roussel, Inc., Route 202-206, P.O. Box 2500, Somerville, NJ.

Address correspondence tc: Dr. Rui-Qian Wan, Biological Psychiatry Branch, National Institute of Mental Health, Bldg. 10/3N212, 9000 Rockville Pike, Bethesda, MD 20892.

Received September 11, 1995; revised August 5, 1996; accepted August 14, 1996. gerts 1993; Randolph et al. 1993; Hall et al. 1994). The hippocampus is anatomically interconnected with many structures in the mesolimbic and mesocortical dopamine (DA) systems (Groenewegen et al. 1991). Hippocampal glutamatergic efferents and dopaminergic efferents from the ventral tegmental area (VTA) converge onto the same neurons in the nucleus accumbens (NAc) (Totterdell and Smith 1989; Groenewegen et al. 1991). This hippocampal-accumbens interaction has been postulated to play an important role in modulating motor behaviors. Rats with hippocampal lesions become highly susceptible to environmental stimulation and psychomotor stimulants such as amphetamine. Thus, hippocampal lesions have been used to produce an animal model for the study of schizophrenia (McKinney and Moran 1981; Schmajuk 1987; Grey et al. 1991; Whishaw and Mittleman 1991).

A series of studies examining the effects of neonatal hippocampal lesions on behavior at different ages in rats has been reported (Lipska and Weinberger 1993; 
Lipska et al. 1993, 1995a, 1995b). Neonatal lesions of the hippocampus were found to induce delayed behavioral impairments that resulted in a hyperresponsiveness to stress and amphetamine at postnatal day 56 (PD56), but not at postnatal day 35 (PD35; Lipska et al. 1993). In rats PD35 and PD56 correspond to puberty and early adulthood, respectively (Ojeda et al. 1980). A previous in vivo microdialysis study of freely moving rats in our laboratory indicated that although amphetamine induced greater locomotion in rats with neonatal hippocampal lesions than in controls, the level of extracellular DA in the NAc was similar in both lesioned and control rats (Wan et al. 1996). This dissociation between an enhanced behavioral responsiveness and a lack of increase in DA release from presynaptic terminals suggested that an increased postsynaptic sensitivity may play an important role in these behavioral impairments. In addition, another study indicated that rats with neonatal hippocampal lesions were behaviorally hyperresponsive to apomorphine, a nonselective DA receptor agonist, at puberty and early adulthood (Lipska and Weinberger 1993). However, the role of the specific subtype of DA receptors in this lesion-induced hypersensitivity has not been identified. Thus, the present study was designed to identify the specific DA receptor subtype that is involved in the mediation of behavioral hyperresponsiveness induced by neonatal hippocampal lesions. Our experiments examined the lesion-induced effect on locomotor responsiveness to $D_{1}$ and $D_{2}$ receptor agonists and antagonists at different ages.

\section{MATERIALS AND METHODS}

\section{Subjects}

Pregnant Sprague-Dawley rats (Charles River) were obtained at 12 to 15 days of gestation. The rats were housed individually and maintained under the standard laboratory conditions as outlined in the "NIH Guide for the Care and Use of Laboratory Animals" (National Institute of Health Publications, No. 85-23, revised 1985) with 12-hour dark-light cycle. Food and water were available ad libitum. Male pups in each litter were used for the experiments. Pups were weaned on postnatal day 25 and grouped two to three per cage according to their surgical status. To maintain a mixed sexual environment for growing pups, two female pups were kept in each litter until weaning. There were 128 male rats included in this study, which were from approximately 24 litters.

\section{Surgery}

Neonatal hippocampal lesions were produced in male pups on postnatal day 7 (PD7). Litters that had four to six male pups were selected for the experiments. The half of the pups in each litter was randomly assigned to the lesioned group. The other half of the pups was the control group.

Bilateral lesions of the ventral hippocampus were performed using a method described previously (Lipska et al. 1993; Wan et al. 1996). Briefly, each of the anesthetized pups (hypothermia on wet ice for about $15 \mathrm{~min}$ ) was placed on a platform that was fastened on a stereotaxic apparatus. The head of the pup was loosely fixed on the platform and the skull was kept flat. After an incision was made in the skin, two injectors made of 32gauge hypodermic tubing were used to deliver drug solution or vehicle. Ibotenic acid (IBO, Sigma, St. Louis, $\mathrm{MO}$ ) was prepared in $0.1 \mathrm{M}$ phosphate buffered saline (PBS, $\mathrm{pH} 7.4$ ) in the concentration of $10 \mu \mathrm{g} / \mu \mathrm{l}$. A volume of $0.3 \mu \mathrm{l} / \mathrm{side}$ of IBO (lesions) or the same volume of PBS (controls) was infused bilaterally into the ventral hippocampus using the stereotaxic coordinates AP $-3.0, \mathrm{ML} \pm 3.5$, and $\mathrm{DV}-4.0 \mathrm{~mm}$ relative to bregma. The flow rate of infusion was $0.15 \mu \mathrm{l} /$ minute. After completion of infusion the injectors remained in the places for another 4 minutes. The incision was closed with two clips. The pup was then placed on a warm water heating pad (American Medical Systems, Cincinnati, $\mathrm{OH})$ at $37^{\circ} \mathrm{C}$ and returned to its mother after its body temperature recovered.

\section{Locomotor Apparatus and Behavioral Assessments}

Each locomotor chamber (clear polycarbonate cage, $45 \times$ $22 \times 20 \mathrm{~cm}$ ) was equipped with three photoelectric light sources spaced at $18-\mathrm{cm}$ intervals and $1 \mathrm{~cm}$ above the grid floor to record horizontal movements. Consecutive interruptions of two separate light beams were registered as activity counts and summarized every 5 minutes by the microprocessor-based control system.

The behavioral tests examined spontaneous exploration, drug-influenced locomotor activity, and stereotyped behavior. For each rat, spontaneous locomotion was recorded during the first 60 minutes. At the end of this period, the rat was injected with either drug or vehicle and returned immediately to the chamber for another 60 minutes. All behavioral assessments took place between 9:00 A.M. and 2:00 P.M.. Stereotyped behaviors were assessed for $30 \mathrm{~s}$ every 10 minutes following injection. Their overall stereotypy was rated on a modified version of the scale that was originally described elsewhere (Maclennan and Maier 1983; Mittleman et al. 1993): 0, no stereotypy; 1 , intermittent stereotypy; 2 , continuous stereotypy over a wide area; and 3 , continuous stereotypy in a restricted area.

\section{Drugs and Experimental Groups}

d-Amphetamine (Sigma, St. Louis, MO), (-)-Quinpirole [Research Biochemicals International (RBI), Nat- 
ick, MA], ( \pm )-SKF-38393 (RBI), SCH-23390 (RBI), and Raclopride (ASTRA, Sodertalje, Sweden) were prepared in saline and administered in an injection volume of 1 $\mathrm{ml} / \mathrm{kg}$. The doses of drugs used in the present study were selected based on the previous studies and our own preliminary experiments (Mittleman et al. 1993; Petry et al. 1993; Wan et al. 1996).

On PD35, rats were examined for their behavioral responses to quinpirole ( 0 (saline), $0.06,0.125,0.25$, and $0.5 \mathrm{mg} / \mathrm{kg} \mathrm{SC}$ ) and SKF (5 and $10 \mathrm{mg} / \mathrm{kg} \mathrm{SC}$ ). Rats in the same lesion status were randomized to each group of the different drugs and doses $(n=8$ at each of the doses for every drug). Rats from the same litter were randomly distributed to different groups.

On PD56, all of the rats were examined again for their behavioral response to quinpirole and SKF at the same doses used on PD35. Groups of the different drugs and doses ( $n=8 /$ group) were formed randomly from rats in the same lesion status. However, the new assignment was made so that each of the rats was tested with a drug or a dose different from that it had received on PD35. Again, rats from the same litter were assigned to different groups. In addition, a new group of controls and a group of lesioned rats ( $n=8 /$ group) were added to examine behavioral responses to quinpirole $(0.125$ $\mathrm{mg} / \mathrm{kg})$ in combination with SKF $(10 \mathrm{mg} / \mathrm{kg})$. SKF was injected 10 minutes prior to quinpirole. These two groups were not tested previously.

On PD70, six groups of controls and six groups of lesioned rats ( $n=8$ /group) were randomly formed from rats that had been tested on PD35 and PD56. This experiment examined the effects of raclopride $(0.25$ and 0.5 $\mathrm{mg} / \mathrm{kg} \mathrm{SC})$ and SCH (0.01 and $0.02 \mathrm{mg} / \mathrm{kg} \mathrm{SC})$ on amphetamine-induced ( $1.5 \mathrm{mg} / \mathrm{kg} \mathrm{IP})$ locomotion. Raclopride or $\mathrm{SCH}$ was injected 10 minutes prior to the injection of amphetamine.

\section{Histology}

At the end of the behavioral assessments, each rat was anesthetized with Nembutal (pentobarbital sodium injection, USP) and perfused transcardially with $4 \%$ formalin-PBS solution. The brain was removed from the skull. After further fixation in formalin solution, the brain was sliced with a freezing cryostat. The sections through the damaged area were saved, mounted, and stained with cresyl violet. Each section was examined under a microscope to determine the location and extent of lesions.

\section{Statistics}

Repeated-measures analysis of variance (ANOVA) was used to analyze behavioral data. Neuman-Keuls posthoc comparisons and Dunnett's $t$-tests were used when appropriate to identify a significant difference between groups.

\section{RESULTS}

\section{Histology}

Bilateral damage to the hippocampus occurred consistently in all rats. The place and size of lesions were similar to that of our previous study (Wan et al. 1996). Figure 1 provides an example of neonatal hippocampal damage. Substantial lesions were observed in the ventral hippocampus that included the CA1, CA3, and dentate gyrus. The lesions were indicated by cavitation, cell loss, and neuroglial proliferation (Figure 2). The dorsal part of the hippocampus, including the CA1, CA3, and dentate gyrus, was generally spared in most of the rats. Isolated small pieces of the ventral dentate, CA3, or CA1 were spared in some rats. Damage to the subiculum was indicated in the posterior portion of the hippocampus in most of the rats. Small damage to the entorhinal and piriform cortices was present in a few rats. However, damage to the adjacent thalamic areas was not detected.

\section{Behavior}

Spontaneous Exploration. Spontaneous exploration as indicated by locomotor activity before injections was not different between control and lesioned groups on PD35 and PD56. An example of similar spontaneous locomotion between two groups is illustrated in Figure 3.

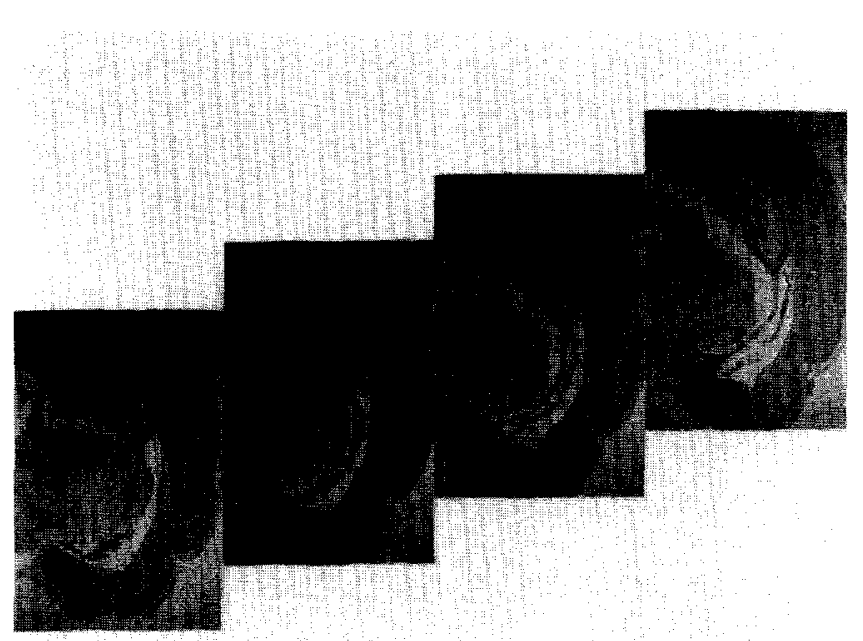

Figure 1. Coronal sections that indicate the place and size of neonatal hippocampal lesions produced by ibotenic acid. Sections were stained with cresyl violet. Anteroposterior atlas coordinates for these coronal sections (from left to right) correspond roughly to -4.30 to $-5.30 \mathrm{~mm}$ posterior to bregma (Paxinos and Watson 1986). 


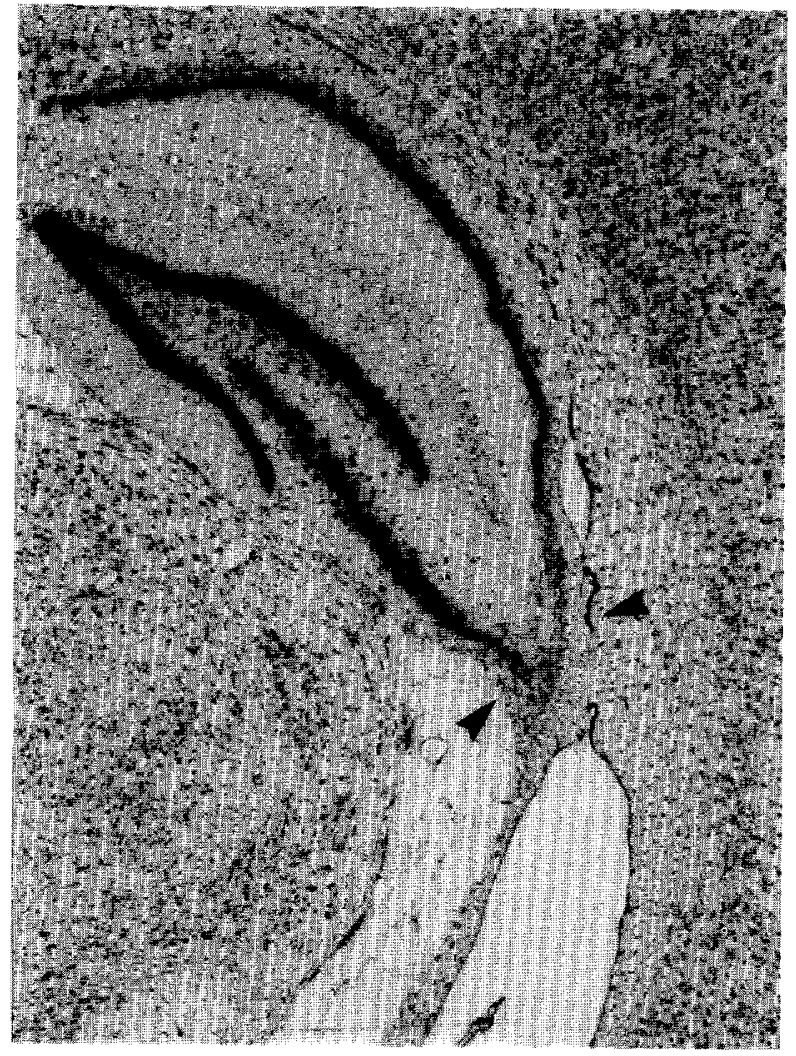

Figure 2. Cresyl violet-stained coronal section that indicates ibotenic acid-induced lesions in the hippocampus. Damage is indicated by cavitation, cell loss, and neuroglial proliferation. Arrows, focal neuronal loss and neuroglial proliferation in the CA2 and CA3 areas. The major part of the dorsal hippocampus is generally spared.

This similar spontaneous exploration between the control and lesioned groups was indicated in the experiments that examined the effects of raclopride and $\mathrm{SCH}$ on amphetamine-induced locomotor activity on PD70 as well.

Effect of Quinpirole. Administration of saline did not influence locomotor activity in either group on PD35 and PD56 (Figure 3). Quinpirole increased the locomotor activity for both groups in a dose-dependent manner (dose, PD35: $F_{4,70}=16.73, p<.001$; PD56: $F_{4,70}=$ $10.25, p<.001)$. At the lowest dose $(0.06 \mathrm{mg} / \mathrm{kg})$, quinpirole suppressed locomotion in both groups relative to saline on both PD35 and PD56 (drug, PD35: $F_{1,28}=$ 21.54, $p<.01$; PD56: $\left.F_{1,28}=27.66, p<.01\right)$. Hippocampal lesions influenced the locomotor response to quinpirole (lesion, PD35: $F_{1,70}=11.78, p<.01$; PD56: $F_{1,70}=$ $8.86, p<.01$; lesion $\times$ dose $\left(F_{4,70}=3.32, p<.05\right)$. At the doses of 0.25 and $0.5 \mathrm{mg} / \mathrm{kg}$, the lesioned group had greater locomotor activity than the control group on PD35 and PD 56 (Figure 3).

Intermittent stereotyped behavior occurred only following the highest dose of quinpirole $(0.5 \mathrm{mg} / \mathrm{kg})$. The frequency of sniffing and rearing behaviors increased on both PD35 and PD56. However, the scores of stereotyped behavior in the lesioned group did not differ from the control group. Both groups exhibited a significant effect of time for the occurrence of stereotyped behavior during the 60 minutes following injection (time, $\mathrm{F}_{5,140}=6.03, p<.01$; Figure 3 , inserts).

Effect of SKF-38393. SKF alone at two doses (5 and 10 $\mathrm{mg} / \mathrm{kg}$ ) did not significantly alter locomotor activity or stereotyped behavior in either group on PD35 and PD56. Lesioned rats did not display a behavioral hypersensitivity to SKF as compared to controls (data not shown).

Effect of Quinpirole in Combination with SKF-38393. Quinpirole $(0.125 \mathrm{mg} / \mathrm{kg})$ in combination with SKF $(10$ $\mathrm{mg} / \mathrm{kg}$ ) markedly enhanced locomotor activity in the lesioned group but not the control group (lesion, $F_{1,28}=$ $4.99, p<.05$; lesion $\times$ drug, $F_{1,28}=5.02, p<.05$; lesion $\times$ drug $\times$ time, $F_{11,308}=2.35, p<.01$, Figure 4$)$. For the lesioned group, quinpirole $(0.125 \mathrm{mg} / \mathrm{kg})$ or SKF $(10 \mathrm{mg} /$ $\mathrm{kg}$ ) alone did not significantly increase locomotion compared to saline, although the quinpirole-induced locomotor activity did show a significant effect over time compared to saline (time, $F_{11,154}=3.41, p<.001$; drug $\times$ time, $F_{11,154}=4.22, p<.001$ ). Following combined administration of quinpirole and SKF, the locomotor activity of lesioned rats was higher than saline (drug, $F_{1,14}=5.74, p<.05$; drug $\times$ time, $F_{11,154}=6.06, p<$ .001 ) and SKF (drug, $F_{1,14}=4.78, p<.05$; drug $\times$ time, $\left.F_{11,154}=5.01, p<.001\right)$. However, the locomotion induced by the combined injection did not significantly differ from that induced by quinpirole alone.

Stereotyped behavior was observed only following injections of quinpirole in combination with SKF (drug, $F_{3,56}=38.04, p<.001$; time, $F_{5,280}=14.65, p<.01$; drug $\times$ time, $F_{15,280}=14.66, p<.01$, Figure 4 , inserts). Stereotypy occurred more frequently in the lesioned group than the control group (lesion, $F_{1,56}=26.84, p<.01$; lesion $\times$ drug $\times$ time, $\left.F_{15,280}=9.41, p<.01\right)$.

Effect of Raclopride on Amphetamine-Induced Locomotion. Amphetamine $(1.5 \mathrm{mg} / \mathrm{kg})$ enhanced locomotor activity in both groups (drug, $F_{1,28}=50.55, p<.001$, Figure 5). The lesioned group had a higher locomotor response to amphetamine than the control group (lesion, $F_{1,28}=4.78, p<.05$; lesion $\times$ drug, $F_{1,28}=6.12, p<0.05$; lesion $\times$ drug $\times$ time, $\left.F_{11,308}=5.02, p<.001\right)$. Raclopride at both doses $(0.25$ and $0.5 \mathrm{mg} / \mathrm{kg})$ abolished amphetamineenhanced locomotion in both groups. For both groups, the locomotor activity following injections of raclopride in combination with amphetamine was significantly lower than that treated with amphetamine alone $\left(p^{\prime} s<.001\right)$, and no difference was observed compared to saline. In lesioned rats, the locomotor activity following combined amphetamine and raclopride injection at the lower dose $(0.25 \mathrm{mg} / \mathrm{kg})$ increased during the later test session, which was indicated by a significant time effect during the 


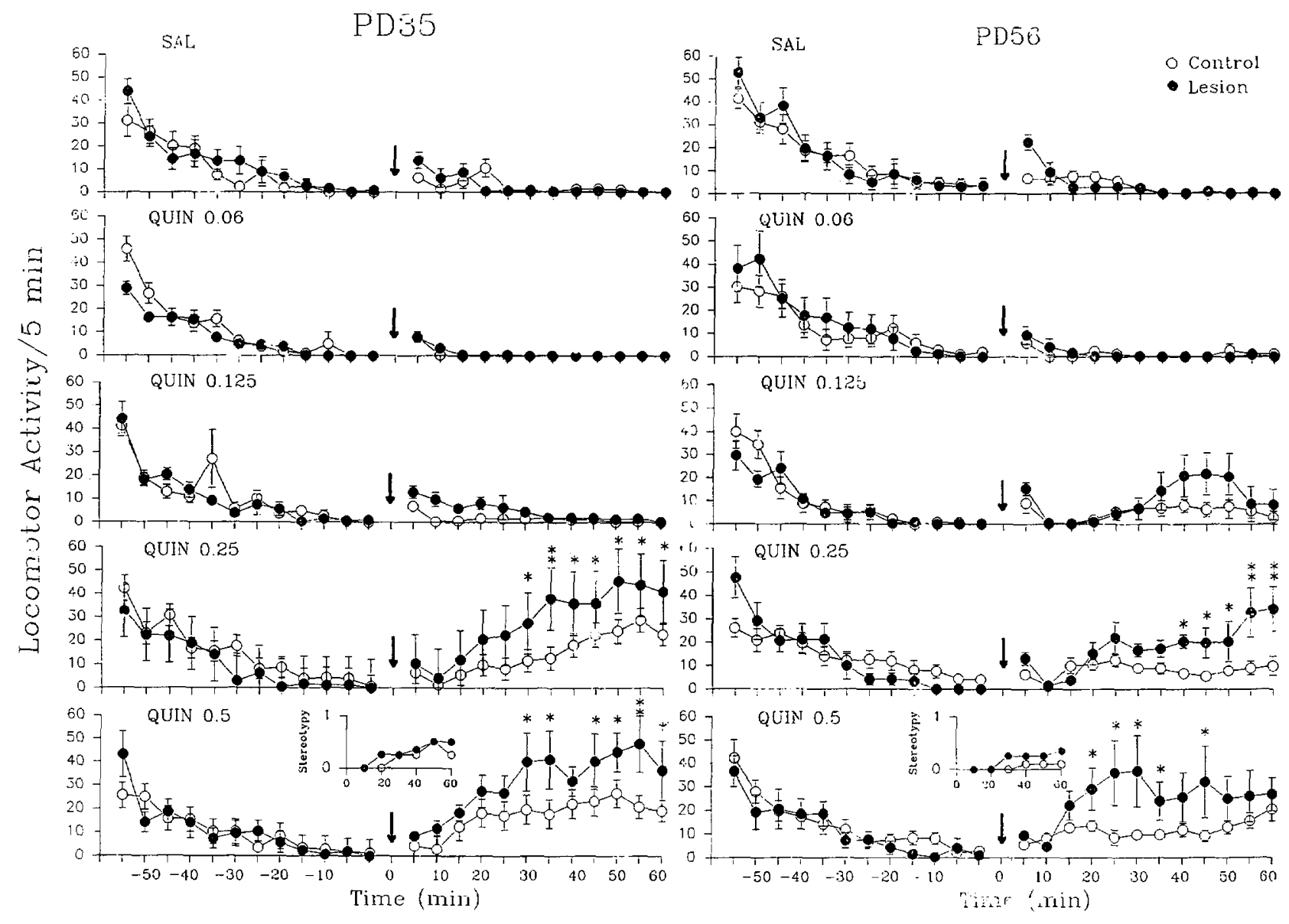

Figure 3. Effect of neonatal hippocampal lesions on quinpirole-induced locomotion (main graphs) and stereotyped behavior (inserts) on PD35 and PD56. Left panel, behavioral responses examined on PD35; right panel, behavioral responses examined on PD56; symbols (Open circles, controls; solid circles, lesions), mean; vertical bars, SEM. Vertical arrows, time of injection. ${ }^{* *} p<$ $.01 ;{ }^{*} p<.05$ versus controls.

60-min period (time, $F_{11,154}=2.83, p<.01$; drug $\times$ time, $F_{11,154}=5.92, p<.001$, Figure 5, right panel).

Stereotyped behavior was found only following administration of amphetamine alone in both groups (drug, $F_{3,56}=115.71, p<.001$; time, $F_{5,280}=25.73, p<.001$; drug $\times$ time, $F_{15,280}=25.73, p<.001$, Figure 5, inserts). The score of stereotypy was higher in the lesioned group than the control group (lesion, $F_{1,56}=20.23, p<.001$; lesion $\times$ drug $\times$ time, $F_{15,280}=6.25, p<.01$ ). Raclopride at both doses suppressed stereotyped behavior induced by amphetamine.

Effect of SCH-23390 on Amphetamine-Induced Locomotion. SCH at both doses $(0.01$ and $0.02 \mathrm{mg} / \mathrm{kg})$ also abolished amphetamine-induced hyperlocomotion in both groups ( $p^{\prime} s<.001$, Figure 6$)$. The locomotor activity following $\mathrm{SCH}$ in combination with amphetamine did not differ from saline.

$\mathrm{SCH}$ at both doses also completely suppressed the amphetamine-induced stereotyped behavior (Figure 6, inserts). Rats injected with the higher dose of SCH $(0.02$ $\mathrm{mg} / \mathrm{kg}$ ) were inactive during almost the entire test session.

\section{DISCUSSION}

\section{Enhancement of Postsynaptic Sensitivity Induced by Neonatal Hippocampal Lesions}

Hippocampal-accumbens interaction has been identified as important in modulating psychomotor activity. The effects of hippocampal lesions on DA release from presynaptic terminals in the NAc have been examined using in vivo microdialysis. Bilateral hippocampal lesions made in adult rats induced locomotor hyperresponsiveness to amphetamine, and this behavioral impairment was related to an increased amphetamine-stimulated DA release in the NAc (Wilkinson et al. 1993). However, our previous microdialysis study in freely moving rats indicated that neonatal hippocampal lesions had no effect on amphetamine-induced DA release in the NAc at PD56, although lesioned rats did show a higher locomotor response to amphetamine than did controls (Wan et al. 1996). These results suggest that neonatal hippocampal lesion-induced behavioral hyperresponsiveness to amphetamine may be related to a postsynaptic DA receptor supersensitivity. 


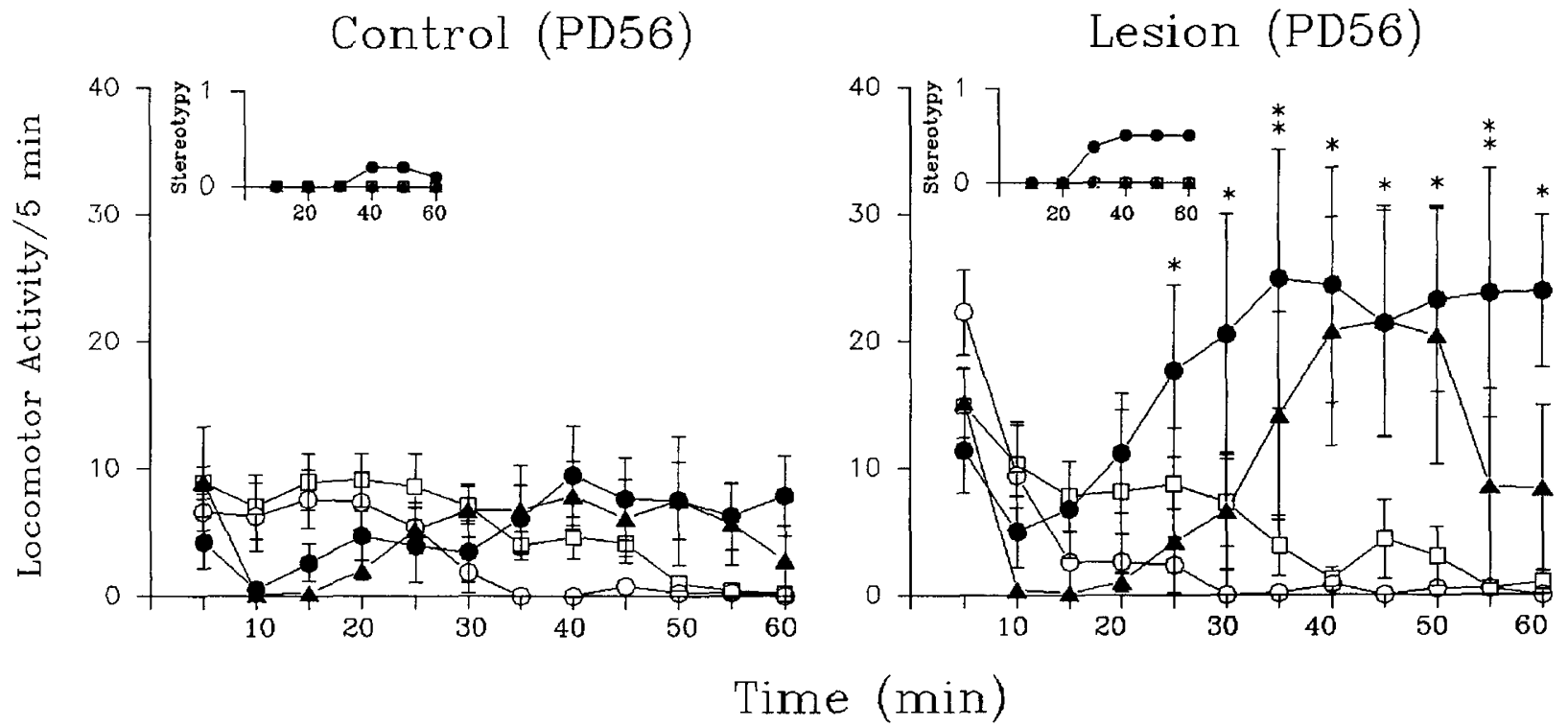

Figure 4. Effect of neonatal hippocampal lesions on locomotion (main graphs) and stereotyped behavior (inserts) induced by quinpirole (triangles, $0.125 \mathrm{mg} / \mathrm{kg}$ ) or SKF38393 (squares, $10 \mathrm{mg} / \mathrm{kg}$ ) alone versus coadministration of quinpirole and SKF38393 (solid circles) on PD56. Left panel, behavioral responses in control rats; right panel, behavioral responses in lesioned rats; (open circles, saline) symbols, mean; vertical bars, SEM. ${ }^{* *} p<.01 ;{ }^{*} p<.05$ versus control rats that received coadministration. See text for other comparisons among treatment.

The present study provides evidence for enhanced postsynaptic DA receptor sensitivity following neonatal hippocampal lesions. The results indicated that quinpirole at the low dose $(0.06 \mathrm{mg} / \mathrm{kg})$ decreased locomo- tion, which was likely due to stimulation of presynaptic autoreceptors (Imperato et al. 1988; Eilam and Szechtman 1989; Barnes et al. 1990; Mogenson and Wu 1991), whereas higher doses $(0.25$ and $0.5 \mathrm{mg} / \mathrm{kg})$ increased

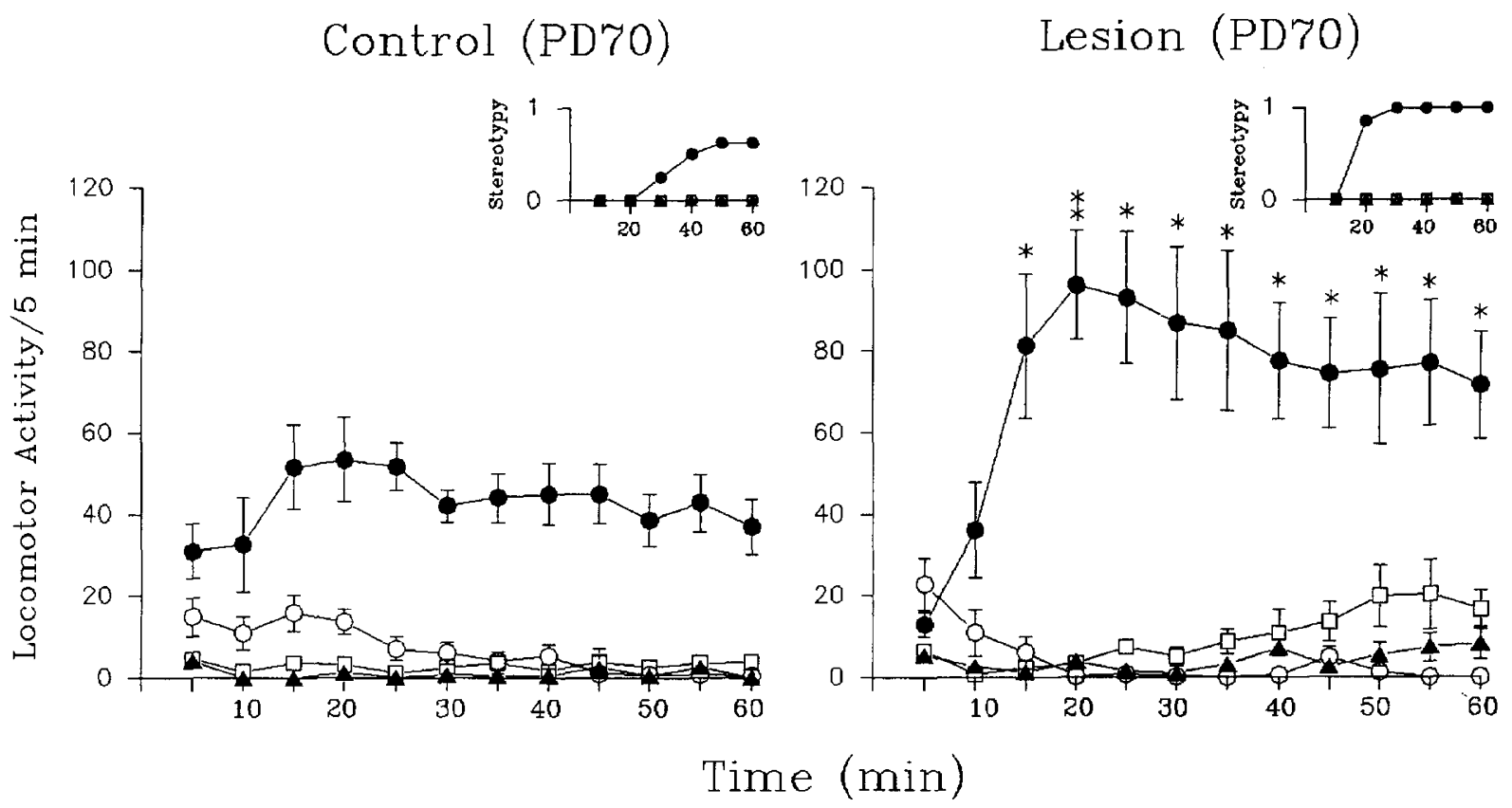

Figure 5. Effect of neonatal hippocampal lesions on locomotion (main graphs) and stereotyped behavior (inserts) induced by amphetamine (solid circles, $1.5 \mathrm{mg} / \mathrm{kg}$ ) alone versus coadministration of amphetamine $(1.5 \mathrm{mg} / \mathrm{kg})$ and raclopride (squares, $0.25 \mathrm{mg} / \mathrm{kg}$; triangles, $0.5 \mathrm{mg} / \mathrm{kg}$ ) on PD70. Left panel, behavioral responses in control rats; right panel, behavioral responses in lesiond rats; open circles, saline; symbols, mean; vertical bars, SEM. ${ }^{* *} p<.01 ;{ }^{*} p<.05$ versus control rats that received amphetamine. See text for other comparisons among treatments. 


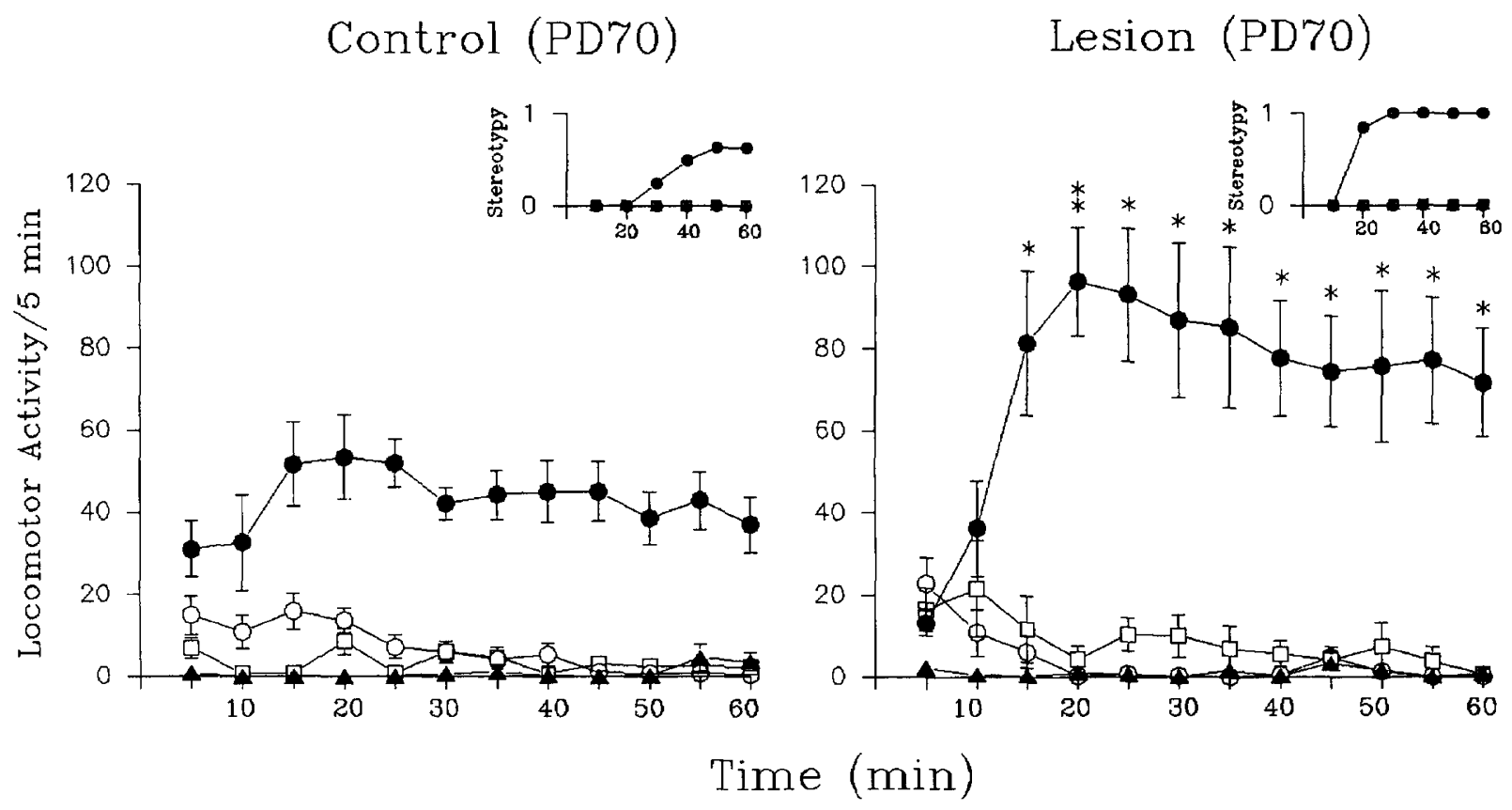

Figure 6. Effect of neonatal hippocampal lesions on locomotion (main graphs) and stereotyped behavior (inserts) induced by amphetamine (solid circles, $1.5 \mathrm{mg} / \mathrm{kg}$ ) alone versus coadministration of amphetamine and SCH23390 (squares, $0.01 \mathrm{mg} / \mathrm{kg}$ and triangles, $0.02 \mathrm{mg} / \mathrm{kg}$ ) on PD70. Left panel, behavioral responses in control rats; right panel, behavioral responses in lesioned rats; open circles, saline; symbols, mean; vertical bars, SEM. ${ }^{* *} p<.01$; ${ }^{*} p<.05$ versus control rats that received amphetamine. See text for other comparisons among treatments.

locomotor activity. These results were consistent with previous reports that quinpirole produced a biphasic effect on locomotion with respect to dose and time course (Eilam and Szechtman 1989; Van Hartesveldt et al. 1992). Of particular importance, however, was the fact that rats with neonatal hippocampal lesions had a behavioral hypersensitivity to quinpirole. This neonatal lesion-induced behavioral impairment was observed in rats at both PD35 and PD56.

The increase in locomotion induced by higher doses of quinpirole may be attributable to its postsynaptic stimulation (Van Hartesveldt et al. 1992; Braun et al. 1993; Yue et al. 1994). One explanation for quinpiroleinduced hyperlocomotion could be the production of an active metabolite based on the late onset of hyperactivity following systemic injection of quinpirole (Gonzalez-Lima et al. 1987; Eilam and Szechtman 1989). Previous studies, however, have suggested that quinpirole at higher doses may directly stimulate postsynaptic $D_{2}$ receptors. The NAc is one of the regions that has a high density of $\mathrm{D}_{2}$ receptors in the rat brain (Gehlert and Wamsley 1985; Gehlert et al. 1992). Intraaccumbens injections of quinpirole produced an early decrease followed quickly by an increase in locomotor activity (Van Hartesveldt et al. 1992). This behavioral biphasic effect induced by quinpirole was similar to that produced by intraaccumbens injections of DA with respect to the time course of the behavioral response (Wachtel et al.
1979). The similarity in the behavioral profiles suggests that quinpirole and DA are alike in their direct stimulation of pre- and postsynaptic DA receptors.

Although our results from microdialysis and behavioral studies suggest that neonatal hippocampal lesions increase the sensitivity of postsynaptic DA receptors, it remains unclear whether this hypersensitivity is the result of an increase in the density of DA receptors. Two independent studies of DA receptor binding using similar neonatal hippocampal lesions have reported inconsistent results. One study indicated that the density of $D_{3}$ receptors was lower in the NAc and that the density of $D_{1}$ receptors was higher in the caudate putamen, with no change in $D_{2}$ receptors in lesioned rats (Flores et al. 1996). The other study showed that the lesions did not alter $D_{2} / D_{3}$ and, $D_{4}$ receptor densities in the dorsolateral and ventrolateral striatum and the NAc (Knable et al. 1994). However, this latter study might not rule out an alteration in $\mathrm{D}_{3}$ receptors because the study did not distinguish between the $D_{2}$ and $D_{3}$ receptor subtypes. A decrease in $\mathrm{D}_{3}$ receptors could have been masked by changes in $D_{2}$ receptors. Postsynaptic $D_{3}$ receptors have been shown to be involved in the modulation of locomotor activity. U99194A, a $\mathrm{D}_{3}$ antagonist, increases locomotion, suggesting that $\mathrm{D}_{3}$ receptors may exert an inhibitory influence on psychomotor activity (Waters et al. 1993, 1994). Moreover, previous binding studies have shown that quinpirole and raclopride bind to the 
$\mathrm{D}_{3}$ receptor subtype in addition to the $\mathrm{D}_{2}$ receptor subtype (Gehlert et al. 1992; Seeman and Van Tol 1994). These data suggest that quinpirole-induced hyperlocomotion in neonatal hippocampally lesioned rats may be related not only to a stimulation of $\mathrm{D}_{2}$ receptors but also to a decrease in the inhibitory effect of $D_{3}$ receptors.

\section{Roles of $D_{1}$ and $D_{2}$ Receptors in Lesion-Induced Hypersensitivity}

Increased sensitivity of the $\mathrm{D}_{2}$ subtype of DA receptors may play an important role in neonatal hippocampal lesion-induced behavioral impairments. Two results in this study support this conclusion. First, the lesioned group showed a behavioral hypersensitivity to quinpirole indicated by hyperlocomotion induced by quinpirole alone in a dose-dependent manner in lesioned rats relative to controls. In contrast, rats with neonatal hippocampal lesions did not show behavioral hypersensitivity to SKF that alone had no significant effect on locomotion in either group. The dosages of SKF ( 5 and $10 \mathrm{mg} / \mathrm{kg}$ ) were found in previous studies to be sufficient to produce effects of SKF on locomotor or stereotyped activities (Eilam et al. 1992; Mittieman et al. 1993). However, we cannot rule out the possibility that SKF alone at a higher dose than $10 \mathrm{mg} / \mathrm{kg}$ might induce differential effects on behavioral responses in lesioned rats compared to controls. Second, raclopride diminished the amphetamine-induced hyperlocomotion and stereotyped behavior. Evidence has suggested that $D_{2}$ receptors may play a primary role in mediating activity of hippocampal accumbens neurons. A previous study indicated that iontophoretic applications of quinpirole or the $\mathrm{D}_{2}$ antagonist sulpiride, but not the $\mathrm{D}_{1}$ antagonist SCH23390, altered excitability of hippocampal accumbens neurons (Yang and Mogenson 1986). Thus, it is likely that the sensitivity of $D_{2}$ receptors in the hippocampal accumbens system may be altered because of a degeneration of hippocampal projections to the NAc following neonatal hippocampal lesions. Similar impairments of $D_{2}$-mediated behaviors have been demonstrated in rats with hippocampal lesions made in adulthood (Mittleman et al. 1993).

Even though $D_{1}$ and $D_{2}$ receptors can produce opposite effects on some behavioral and neurochemical responses (Eilam et al. 1991, 1992), activation of both $D_{1}$ and $D_{2}$ receptors has been shown to be necessary to achieve the full range of expression of DA-mediated behaviors (Clark and White 1987; Waddington 1989; Walters et al. 1987). Previous studies have indicated that coadministration of $D_{1}$ and $D_{2}$ agonists produced synergistic effects on behavioral responses, effects that could not be induced by the activation of either receptor alone (Amalric et al. 1986; Barone et al. 1986; Molly et al. 1986; Robertson and Robertson 1986; White et al. 1988; Dreher and Jackson 1989). The results of the present study indicate that activation of $D_{1}$ receptors is necessary for amphetamine-induced behaviors because $\mathrm{SCH}$ abolished amphetamine-induced hyperlocomotion in both control and lesioned groups. These results are consistent with those of the previous studies (Molly et al. 1986; Petry et al. 1993). In the present study, however, coadministration of quinpirole and SKF did not significantly increase locomotion in control rats. This lack of effect may be attributed to the doses of the two drugs administered and to the differences in experimental methodology between the present and previous studies (Dreher and Jackson 1989; White et al. 1988). Of importance was that coadministration of both quinpirole and SKF significantly increased locomotion only in lesioned rats compared to the treatment with saline or SKF alone. Although this effect was not significantly higher than that produced by quinpirole alone, the locomotor response following coadministration of the two drugs had a more rapid onset and a longer duration than that produced by quinpirole alone. This result provides additional evidence for the presence of neonatal hippocampal lesion-induced postsynaptic hypersensitivity of DA receptors.

In summary, the results of the present study extend previous findings indicating that there was no neonatal hippocampal lesion-induced effect on DA release in the NAc, although lesioned rats displayed locomotor hyperresponsiveness to amphetamine. The data from the present study indicate that behavioral hyperresponsiveness in lesioned rats is likely due to the enhanced postsynaptic sensitivity of $D_{2}$ receptors.

\section{ACKNOWLEDGMENT}

The authors thank Dona Cramer, Ellen Soly, Doug Rush, and Melinda Cilio for their excellent help in preparing the histological samples for this study and Susan Weiss, Ann Woods, and Chris Hough for their help in preparing this manuscript.

\section{REFERENCES}

Amalric M, Koob GF, Creese I, Swerdlow NR (1986): "Selective" $D_{1}$ and $D_{2}$ receptor antagonists fail to differentially alter supersensitive locomotor behavior in the rat. Life Sci 39:1985-1993

Barnes JM, Barnes NM, Costall B, Naylor RJ (1990): The actions of $(-)-\mathrm{N}$-propylnorapomorphine and selective dopamine $D_{1}$ and $D_{2}$ receptor agonists to modify the release of $\left[{ }^{3} \mathrm{H}\right]$ dopamine from the rat nucleus accumbens. Neuropharmacology 29:327-336

Barone P, Davis TA, Braun A, Chase TN (1986): Dopaminergic mechanisms and motor function: Characterization of $\mathrm{D}_{1}$ and $\mathrm{D}_{2}$ dopamine receptor interactions. Eur J Pharmacol 123:109-114

Beckmann H, Gattaz WF, Jakob H (1987): Biochemical and 
neuropathological indices for the aetiology of schizophrenia. In Haffiner H, Gattaz WF, Janzarik W (eds), Search for the Causes of Schizophrenia. Springer-Verlag, New York

Bloom FE (1993): Advancing a neurodevelopmental origin for schizophrenia. Arch Gen Psychiatry 50:224-227

Bogerts B (1993): Recent advances in the neuropathology of schizophrenia. Schizophr Bull 19:431-445

Braun AR, Jaskiw GE, Vladar K, Sexton RH, Kolachana BS, Weinberger DR (1993): Effects of ibotenic acid lesions of the medial prefrontal cortex on dopamine agonistrelated behaviors in the rat. Pharmacol Biochem Behav 46:51-60

Brown R, Colter N, Corsellis JAN, Crow TJ, Frith CD, Jagoe R, Johnstone EC, March L (1986): Postmortem evidence of structural brain changes in schizophrenia: Differences in brain weight, temporal horn area, and parahippocampal gyrus compared with affective disorder. Arch Gen Psychiatry 43:36-42

Clark D, White FJ (1987): $D_{1}$ dopamine receptor--The search for a function: $A$ critical evaluation of the $D_{1} / D_{2}$ dopamine receptor classification and its functional implications. Synapse 1:347-388

Dreher JK, Jackson DM (1989): Role of $D_{1}$ and $D_{2}$ dopamine receptors in mediating locomotor activity elicited from the nucleus accumbens of rats. Brain Res 487:267-277

Eilam D, Szechtman H (1989): Biphasic effect of $D_{2}$ agonist quinpirole on locomotion and movements. Eur J Pharmacol 161:151-157

Eilam D, Clements KVA, Szechtman H (1991): Differential effects of $D_{1}$ and $D_{2}$ dopamine agonists on stereotyped locomotion in rats. Behav Brain Res 45:117-124

Eilam D, Talangbayan H, Canaran G, Szechtman H (1992): Dopaminergic control of locomotion, mouthing, snout contact, and grooming: Opposing roles of $D_{1}$ and $D_{2}$ receptors. Psychopharmacology 106:447-454

Falkai P, Bogerts B (1986): Cell loss in the hippocampus of schizophrenics. Eur Arch Psychiatry Neurol Sci 236: 154-161

Flores G, Barbeau D, Quirion R, Srivastava LK (1996): Decreased binding of dopamine $D_{3}$ receptors in limbic subregions after neonatal bilateral lesion of rat hippocampus. J Neurosci 16:2020-2026

Gehlert DR, Wamsley JK (1985): Dopamine receptors in the rat brain: Quantitative autoradiographic localization using $\left[{ }^{3} \mathrm{H}\right]$ sulpiride. Neurochem Int 7:717-723

Gehlert DR, Gackenheimer SL, Seeman P, Schaus J (1992): Autoradiographic localization of ${ }^{3} \mathrm{H}$-quinpirole binding to $\mathrm{D}_{2}$ and $\mathrm{D}_{3}$ receptors in rat brain. Eur J Pharmacol 211:189-194

Gonzalez-Lima F, Hart WT, Rivera-Quinones C (1987): Metabolite involvement in the behavioral effects of bromocriptine in cats. Eur J Pharmacol 141:109-115

Gray JA, Feldon J, Rawlins JNP, Hemsley DR, Smith AD (1991): The neuropsychology of schizophrneia. Behav Brain Sci 14:1-84

Groenewegen HJ, Berebdse HW, Meredith GE, Haber SN, Voorn P, Wolters JG, Lohman AHM (1991): Functional anatomy of the ventral, limbic system-innervated striatum. In Willner P, Scheel-Kruger J (eds), The Mesolim- bic Dopamine System: From Motivation to Action. Wiley, Chichester, pp 19-59

Hall LD, Herrod JJ, Carpenter TA, McKenna PJ (1994): Magnetic resonance imagine in schizophrenia: A review of clinical and methodological issues. In Ancill RJ, Holliday S, Hihenbottam J (eds), Schizophrenia: Exploring the Spectrum of Psychosis. Wiley, Chichester, pp 115135

Imperato A, Tanda G, Frau R, DiChira G (1988): Pharmacological profile of dopamine receptor agonists as studied by brain dialysis in behaving rats. J Pharmacol Exp Ther 245:257-264

Kerwin RW, Murray RM (1992): A developmental perspective on the pathology and neurochemistry of the temporal lobe in schizophrenia. Schizophr Res 7:1-12

Knable MB, Murray AM, Lipska BK, Karoum F, Weinberger DR (1994): $D_{2} / D_{3}$ and $D_{4}$ receptor densities are not altered in rats with neonatal hippocampal damage. Soc Neurosci Abstr 513.3

Kotrla KJ, Weinberger DR (1994): A neurodevelopmental perspective on normal brain functioning, plasticity and schizophrenia. In Ancill RJ, Holliday S, Hihenbottam J (eds), Schizophrenia: Exploring the Spectrum of Psychosis. Wiley, Chichester, pp 67-93

Lipska BK, Weinberger DR (1993): Delayed effects of neonatal hippocampal damage on haloperidol-induced catelepsy and apomorphine-induced stereotypic behaviors in the rat. Dev Brain Res 75:213-222

Lipska BK, Jaskiw GE, Weinberger DR (1993): Postpubertal emergence of hyperresponsiveness to stress and to amphetamine after neonatal excitotoxic hippocampal damage: A potential animal model of schizophrenia. Neuropsychopharmacology 9:67-75

Lipska BK, Chrapusta SJ, Egan MF, Weinberger DR (1995a); Neonatal excitotoxic ventral hippocampal damage alters dopamine response to mild repeated stress and to chronic haloperidol. Synapse 20:125-130

Lipska BK, Swerdlow NR, Geyer MA, Jaskiw GE, Braff DL, Weinberger DR (1995b): Neonatal excitotoxic hippocampal damage in rats causes post-pubertal changes in prepulse inhibition of startle and its disruption by apomorphine. Psychopharmacology 122:35-43

MacLennan AJ, Maier SF (1983): Coping and the stressinduced potentiation of stimulant stereotypy in the rat. Science 219:1091-1093

McKinney WT, Moran EC (1981): Animal models of schizophrenia. Am J Psychiatry 138:478-483

Mednick SA, Cannon TD, Barr CE, Lyon M (1991): Fetal Neural Development and Adult Schizophrenia. Cambridge, Cambridge University Press

Mittleman G, LeDuc PA, Whishaw IQ (1993): The role of $D_{1}$ and $D_{2}$ receptors in the heightened locomotion induced by direct and indirect dopamine agonists in rats with hippocampal damage: An animal analogue of schizophrenia. Behav Brain Res 55:253-267

Mogenson GJ, Wu M (1991): Effects of administration of dopamine $\mathrm{D}_{2}$ agonist quinpirole on exploratory locomotion. Brain Res 551:216-220

Molly AG, O'Boyle KM, Pugh MT, Waddington AL (1986): Locomotor behaviors in response to new selective $D_{1}$ and $D_{2}$ dopamine receptor agonists, and the influence of 
selective antagonists. Pharmacol Biochem Behav 25: 249-253

Ojeda SR, Andrews WW, Advis JP, Smith White S (1980): Recent advances in the endocrinology of puberty. Endocrine Rev 1:228-257

Paxinos G, Watson C (1986): The rat brain in sterotaxic coordinates, 2nd ed. New York, Acadmic Press

Petry N, Furmidge L, Tong Z-Y, Martin C, Clark D (1993): Time sampling observation procedure for studying drug effects: Interaction between d-amphetamine and selective dopamine receptor antagonists in the rat. Pharmacol Biochem Behav 44:167-180

Randolph C, Goldberg TE, Weinberger DR (1993): The neuropsychology of schizophrenia. In Heilman KM, Valenstein E (eds) Clinical Neuropsychology, 3rd ed. Oxford, New York, pp 499-522

Robertson GS, Robertson HA (1986): Synergistic effects of $D_{1}$ and $D_{2}$ dopamine agonists on turning behavior in rats. Brain Res 384:387-390

Schmajuk NA (1987): Animal models for schizophrenia: The hippocampally lesioned animal. Schizophr Bull 13:317327

Seeman P, Van Tol HHM (1994): Dopamine receptor pharmacology. TiPS 15:264-270

Totterdell S, Smith AD (1989): Convergence of hippocampal and dopaminergic input onto identified neurons of the nucleus accumbens of the rat. J Chem Neuroanat 2:285298

Van Hartesveldt C, Cottrell GA, Potter T, Meyer ME (1992): Effects of intracerebral quinpirole on locomotion in rats. Eur J Pharmacol 214:27-32

Wachtel H, Ahlenius S, Andén N-E (1979): Effects of locally applied dopamine to the nucleus accumbens on the motor activity of normal rats and following $\alpha$-methyltyrosine reserpine. Psychopharmacology 63:203-206

Waddington JL (1989): Functional interactions between $D_{1}$ and $\mathrm{D}_{2}$ dopamine receptor systems: Their role in the regulation of psychomotor behavior, putative mechanisms, and clinical relevance. J Psychopharmacol 3:54-63
Walters JR, Bergstrom DA, Carlson JH, Chase TN, Braun AR (1987): $D_{1}$ dopamine receptor activation required for postsynaptic expression of $\mathrm{D}_{2}$ agonist effects. Science 236:719-722

Wan RQ, Giovanni A, Kafka SH, Corbett R (1996): Neonatal hippocampal lesions induced hyperresponsiveness to amphetamine: Behavioral and microdialysis studies. Behav Brain Res 78:211-213

Waters N, Svensson K, Haadsma-Svensson Smith MW, Carlsson (1993): The dopamine $\mathrm{D}_{3}$-receptor: A postsynaptic receptor inhibitory on rat locomotor activity. J Neural Transm 94:11-19

Waters N, Lofberg L, Haadsma-Svensson Svensson K, Sonesson C, Carlsson A (1994): Differential effects of dopamine $D_{2}$ and $D_{3}$ receptor antagonists in regard to dopamine release, in vivo receptor displacement and behavior. J Neural Transm 98:39-55

Weinberger DR (1987): Implication of normal brain development for the pathogenesis of schizophrenia. Arch Gen Psychiatry 44:660-669

Whishaw IQ, Mittleman G (1991): Hippocampal modulation of nucleus accumbens: Behavioral evidence from amphetamine-induced activity profiles. Behav Neural Biol 55: 289-306

White FJ, Bednarz LM, Wachtel SR, Hjorth S, Brooderson RJ (1988): Is stimulation of both $D_{1}$ and $D_{2}$ receptors necessary for the expression of dopamine-mediated behaviors? Pharmacol Biochem Behav 30:189-193

Wilkinson LS, Mittleman G, Torres E, Humby T, Hall FS, Robbins TW (1993): Enhancement of amphetamineinduced locomotor activity and dopamine release in nucleus accumbens following excitotoxic lesions of the hippocampus. Behav Brain Res 55:143-150

Yang CR, Mogenson GJ (1986): Dopamine enhances terminal excitability of hippocampal-accumbens neurons via $D_{2}$ receptor: Role of dopamine in presynaptic inhibition. J Neurosci 6:2470-2478

Yue J-L, Nakamura S, Ueda H, Misu Y (1994): Endogenously released L-dopa itself tonically functions to potentiate postsynaptic $\mathrm{D}_{2}$ receptor-mediated locomotor activity of conscious rats. Neurosci Let 170:107-110 